\title{
Synthesis and characterization of electrospun molybdenum dioxide-carbon nanofibers as sulfur matrix additives for rechargeable lithium-sulfur battery applications
}

\author{
Ruiyuan Zhuang ${ }^{\ddagger 1}$, Shanshan Yao ${ }^{*}{ }^{\ddagger 1}$, Maoxiang Jing ${ }^{1}$, Xiangqian Shen ${ }^{1,2}$, Jun Xiang ${ }^{3}$, \\ Tianbao $\mathrm{Li}^{2}$, Kesong Xiao ${ }^{2}$ and Shibiao Qin ${ }^{2}$
}

\author{
Full Research Paper \\ Address: \\ ${ }^{1}$ Institute for Advanced Materials, College of Materials Science and \\ Engineering, Jiangsu University, Zhenjiang, 212013, P. R. China, \\ ${ }^{2}$ Hunan Engineering Laboratory of Power Battery Cathode Materials, \\ Changsha Research Institute of Mining and Metallurgy, Changsha, \\ 412212, P. R. China and ${ }^{3}$ School of Mathematics and Physics, \\ Jiangsu University of Science and Technology, Zhenjiang, 212013, \\ P. R. China \\ Email: \\ Shanshan Yao* - yaosshan@ujs.edu.cn \\ * Corresponding author $\ddagger$ Equal contributors \\ Keywords: \\ electrochemical performance; electrospinning; lithium-sulfur batteries; \\ $\mathrm{MoO}_{2}-\mathrm{CNFs}$; sulfur matrix
}

Beilstein J. Nanotechnol. 2018, 9, 262-270.

doi:10.3762/bjnano.9.28

Received: 29 July 2017

Accepted: 25 December 2017

Published: 24 January 2018

Associate Editor: N. Motta

(C) 2018 Zhuang et al.; licensee Beilstein-Institut.

License and terms: see end of document.

\footnotetext{
Abstract

One-dimensional molybdenum dioxide-carbon nanofibers $\left(\mathrm{MoO}_{2}-\mathrm{CNFs}\right)$ were prepared using an electrospinning technique followed by calcination, using sol-gel precursors and polyacrylonitrile (PAN) as a processing aid. The resulting samples were characterized by X-ray diffraction (XRD), Fourier transform infrared spectroscopy (FTIR), Raman spectroscopy, Brunauer-Emmet-Teller (BET) surface area measurements, scanning electron microscopy (SEM) and transmission electron microscopy (TEM). $\mathrm{MoO}_{2}-\mathrm{CNFs}$ with an average diameter of $425-575 \mathrm{~nm}$ obtained after heat treatment were used as a matrix to prepare sulfur/ $\mathrm{MoO}_{2}-\mathrm{CNF}$ cathodes for lithium-sulfur $(\mathrm{Li}-\mathrm{S})$ batteries. The polysulfide adsorption and electrochemical performance tests demonstrated that $\mathrm{MoO}_{2}-\mathrm{CNFs}$ did not only act as polysulfide reservoirs to alleviate the shuttle effect, but also improve the electrochemical reaction kinetics during the charge-discharge processes. The effect of $\mathrm{MoO}_{2}-\mathrm{CNF}$ heat treatment on the cycle performance of sulfur $/ \mathrm{MoO}_{2}-\mathrm{CNFs}$ electrodes was examined, and the data showed that $\mathrm{MoO}_{2}-\mathrm{CNFs}$ calcined at $850{ }^{\circ} \mathrm{C}$ delivered optimal performance with an initial capacity of $1095 \mathrm{mAh} \mathrm{g}^{-1}$ and $860 \mathrm{mAh} \mathrm{g}^{-1}$ after 50 cycles. The results demonstrated that sulfur/ $\mathrm{MoO}_{2}-\mathrm{CNF}$ composites display a remarkably high lithium-ion diffusion coefficient, low interfacial resistance and much better electrochemical performance than pristine sulfur cathodes.
} 


\section{Introduction}

Lithium-sulfur ( $\mathrm{Li}-\mathrm{S})$ batteries are considered to be the most promising candidates for the next green rechargeable batteries due to their high energy density $\left(2600 \mathrm{Wh} \mathrm{kg}^{-1}\right)$ and theoretical specific capacity $\left(1675 \mathrm{mAh} \mathrm{g}^{-1}\right)$. However, before Li-S batteries become a viable technology, some challenges need to be solved such as the insulating nature of sulfur and the shuttle effect caused by dissolved polysulfide molecules [1]. All of these issues still pose a challenge to overcome for the production of reversible, stable, and efficient sulfur cathodes. The currently proposed approaches to solve these issues include sulfurbased cathode modification, electrolyte modification and new cell configuration [2].

Overall, it is critical to enhance the utilization of sulfur and stabilize the polysulfide within the cathodic region to yield $\mathrm{Li}-\mathrm{S}$ batteries with improved electrochemical performance. For the past two decades, various carbon materials (e.g., mesoporous carbon [3], multiwalled carbon nanotubes (MWNTs) [4] and hollow carbon microspheres [5]) and electrically conductive polymeric materials (e.g., polyaniline [6], polypyrrole [7] and poly(3,4-ethylenedioxythiophene) [8]) have been considerably used to encapsulate sulfur or polysulfide. Recently, polar metal oxide/sulfide materials including $\mathrm{SiO}_{2}$ [9], $\mathrm{TiO}_{2}$ [10], $\mathrm{MnO}_{2}$ [11], $\mathrm{Mg}_{0.6} \mathrm{Ni}_{0.4} \mathrm{O}$ [12], $\mathrm{TiS}_{2}$ [13], $\mathrm{CoS}_{2}$ [14], and $\mathrm{FeS}_{2}$ [15] were found to be more highly effective in binding with sulfur species than carbon substrates, and were found to significantly improve the cycling behavior of $\mathrm{Li}-\mathrm{S}$ batteries. However, these metal oxide/sulfide materials have low electrical conductivity, which makes the chemically adsorbing polysulfides difficult to be reduced directly on the matrix surface, resulting in the lower reutilization of the active sulfur material. In order to improve the kinetics of the electrode redox reaction, the electrical conductivity of $\mathrm{Ti}_{4} \mathrm{O}_{7}$ nanoparticles $[16,17]$ and $\mathrm{Co}_{9} \mathrm{~S}_{8}[18]$ nanosheets have been used in new concepts for sulfur matrices with both a polar nature and good conductivity. Therefore, the exploration of novel conductive composites is another direction leading to the practical application of $\mathrm{Li}-\mathrm{S}$ batteries.

Molybdenum dioxide $\left(\mathrm{MoO}_{2}\right)$ materials are particularly attractive among the transition-metal oxides due to their high melting point, high chemical stability and low electrical resistivity $\left(190 \mathrm{~S} \mathrm{~cm}^{-1}\right)$. This material has great potential for applications in several fields such as sensing, catalysis, supercapacitors and as an anode material in lithium ion batteries due to its relatively large theoretical capacity [19-21]. Although numerous synthetic approaches have been reported for preparing $\mathrm{MoO}_{2}$ nanostructures with diverse morphologies, the fabrication, manipulation, and engineering of one-dimensional (1D) $\mathrm{MoO}_{2}-\mathrm{CNFs}$ nanocomposites, especially with secondary $\mathrm{MoO}_{2}$ nanostructures, are difficult to achieve due to lack of appropriate and generalized synthetic methodologies. Recently, hierarchical $\mathrm{MoO}_{2} / \mathrm{C}$ microspheres and hierarchical $\mathrm{MoO}_{2} / \mathrm{Mo}_{2} \mathrm{C} / \mathrm{C}$ hybrid nanowires were fabricated using organic-inorganic precursors and self-templates, which were used as anode materials in lithium ion batteries [22,23]. However, since electrospinning is a simple and versatile method for producing fibers from a variety of materials on a large scale, it has attracted much attention in both research and commerce [24]. The nanofibers have extremely high specific surface area because of their small diameter and their porosity which exhibits excellent pore interconnectivity $[25,26]$. To the best of our knowledge, no articles related to using $\mathrm{MoO}_{2}-\mathrm{CNFs}$ as a sulfur matrix in $\mathrm{Li}-\mathrm{S}$ batteries have been published so far.

In the present work, a facile route based on a single-spinneret electrospinning technique with a subsequent annealing process was developed to prepare $\mathrm{MoO}_{2}-\mathrm{CNF}$. The effect of $\mathrm{MoO}_{2}-\mathrm{CNF}$ heat treatment on the cycle performance of sulfur/ $\mathrm{MoO}_{2}-\mathrm{CNF}$ s electrodes was examined. The data showed that $\mathrm{MoO}_{2}-\mathrm{CNF}$ s calcined at $850{ }^{\circ} \mathrm{C}$ delivered optimal performance, with an initial capacity of $1095 \mathrm{mAh} \mathrm{g}^{-1}$ and retained a capacity of $860 \mathrm{mAh} \mathrm{g}^{-1}$ after 50 cycles. The results demonstrated that the sulfur/ $\mathrm{MoO}_{2}-\mathrm{CNF}$ composite displays a markedly high lithium-ion diffusion coefficient, a low interfacial resistance and much better electrochemical performance than a pristine sulfur cathode.

\section{Results and Discussion Characterization of $\mathrm{MoO}_{2}-\mathrm{CNFs}$}

$\mathrm{X}$-ray diffraction (XRD) patterns of the as-prepared composite fibers calcined at various temperatures are presented in Figure 1a. Well-defined features appeared for the samples heated at $550{ }^{\circ} \mathrm{C}$ due to the crystallization of $\mathrm{MoO}_{2}$. Five main peaks at $2 \theta$ of $25.8^{\circ}, 36.8^{\circ}, 53.4^{\circ}, 60.4^{\circ}$ and $66.7^{\circ}$ were assigned to the crystallographic planes of (011), (200), (220), (310) and (202), respectively. These corresponded to pure phase $\mathrm{MoO}_{2}$ with monoclinic symmetry, which agreed well with the JCPDS card of $\mathrm{MoO}_{2}$ (78-1072). As the calcination temperature was raised to $850^{\circ} \mathrm{C}$, the characteristic diffraction peaks of $\mathrm{MoO}_{2}$ became sharper and displayed higher intensities, indicating an increase in the crystallinity of $\mathrm{MoO}_{2}$ as shown in Table 1. Meanwhile, this was also reflected in the surface area, which decreased as the calcination temperature increased (Table 1).

The lattice parameters of the as-prepared $\mathrm{MoO}_{2}$ nanoparticles are listed in Table 2. The lattice parameters of the $\mathrm{MoO}_{2}$ phase decreased as the calcination temperature increased, which also reflects the change produced by the varying size of the $\mathrm{MoO}_{2}$ nanoparticles. At the calcination temperature of $900{ }^{\circ} \mathrm{C}$, the pri- 

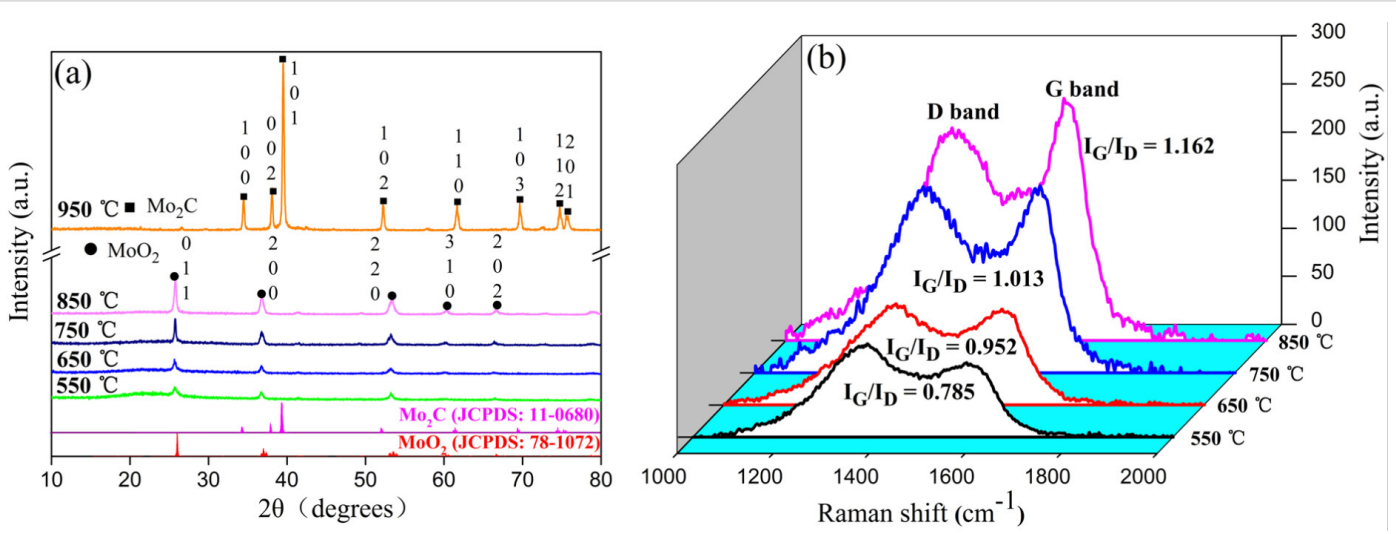

Figure 1: (a) XRD pattern and (b) Raman spectra of the $\mathrm{MoO}_{2}-\mathrm{CNFs}$ calcined at various temperatures.

Table 1: Effect of calcination temperature on BET surface area and particle size of $\mathrm{MoO}_{2}$

\begin{tabular}{lll}
$\begin{array}{l}\text { Calcination } \\
\text { temperature }\left({ }^{\circ} \mathrm{C}\right)\end{array}$ & $\begin{array}{l}\text { BET surface area } \\
\left(\mathrm{m}^{2} \mathrm{~g}^{-1}\right)\end{array}$ & Particle size $(\mathrm{nm})^{\mathrm{a}}$ \\
\hline 550 & 312.65 & 42.93 \\
650 & 226.30 & 50.67 \\
750 & 182.33 & 58.48 \\
850 & 142.69 & 68.24 \\
\hline
\end{tabular}

${ }^{\mathrm{a} C a l c u l a t e d}$ using the Scherrer equation.

mary phase of the sample became $\mathrm{Mo}_{2} \mathrm{C}$, but small diffraction peaks of $\mathrm{MoO}_{2}$ could be identified. After calcination at $950{ }^{\circ} \mathrm{C}$, the $\mathrm{MoO}_{2}$ nanoparticles reacted with carbon during the carbonation process to form $\mathrm{Mo}_{2} \mathrm{C}$, according to Equation 1:

$$
\mathrm{MoO}_{2}+\mathrm{C} \rightarrow \mathrm{Mo}_{2} \mathrm{C}+\mathrm{CO}_{x}
$$

$\mathrm{Mo}_{2} \mathrm{C}$ is known to be active in numerous reactions associated with noble metals, such as $\mathrm{CO}_{2}$ hydrogenation, water gas shift, alcohol synthesis and hydrazine decomposition. Here, $\mathrm{CH}_{4} / \mathrm{H}_{2}$ atmosphere was not used during calcination, which was much safer and facile when compared to other methods [27].

Table 2: Effect of calcination temperature on BET surface area and particle size of $\mathrm{MoO}_{2}$.

\begin{tabular}{llll} 
Sample & $a(\AA)$ & $b(\AA)$ & $V\left(\AA^{3}\right)$ \\
\hline $\mathrm{MoO}_{2}-\mathrm{CNF}\left(550^{\circ} \mathrm{C}\right)$ & 5.6512 & 4.8633 & 132.9862 \\
$\mathrm{MoO}_{2}-\mathrm{CNF}\left(650^{\circ} \mathrm{C}\right)$ & 5.6343 & 4.8602 & 132.1328 \\
$\mathrm{MoO}_{2}-\mathrm{CNF}\left(750^{\circ} \mathrm{C}\right)$ & 5.6203 & 4.8573 & 131.9487 \\
$\mathrm{MoO}_{2}-\mathrm{CNF}\left(850^{\circ} \mathrm{C}\right)$ & 5.6128 & 4.8535 & 131.8365 \\
$\mathrm{MoO}_{2}(\mathrm{JCPDS}: 78-1072)$ & 5.6500 & 4.8600 & 132.9500
\end{tabular}

Raman spectroscopy is a very useful tool for the characterization of carbon-based nanostructures. The Raman spectra of the products excited with a $532 \mathrm{~nm}$ laser line are shown in Figure $1 \mathrm{~b}$. Two characteristic peaks at around 1355 and $1580 \mathrm{~cm}^{-1}$ correspond to disordered carbon (D-band) and graphite carbon (G-band), respectively. Integrating of the areas of the D and $\mathrm{G}$ peaks yielded a significant enhancement in the corresponding $I_{\mathrm{G}} / I_{\mathrm{D}}$ ratio. Thus, it could be concluded that an increased calcination temperature led to the formation of significant amounts of graphitic carbon. Both the XRD and Raman spectra revealed that $\mathrm{MoO}_{2}-\mathrm{CNF}$ was successfully prepared through electrospinning.

The Fourier transform infrared spectroscopy (FTIR) spectra of PAN fibers, as-prepared composite PAN/PMA fibers, and composite fibers calcined at different temperatures are illustrated in Figure 2. The FTIR spectra of PAN fibers and as-prepared PAN/PMA fibers presented characteristic absorption peaks at $2242 \mathrm{~cm}^{-1}(-\mathrm{C} \equiv \mathrm{N})$ and $1736 \mathrm{~cm}^{-1}(\mathrm{C}=\mathrm{O})$, indicating that PAN

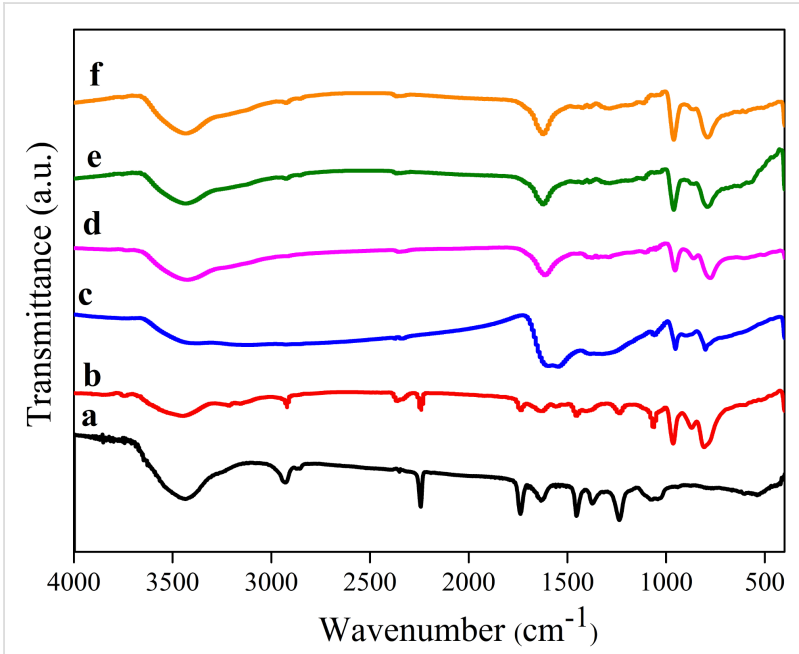

Figure 2: FTIR spectra of (a) PAN fibers and $\mathrm{MoO}_{2}-\mathrm{CNFs}$ (b) as-prepared PAN/PMA composite fibers, and (c-f) fibers calcined at $550^{\circ} \mathrm{C}$, $650^{\circ} \mathrm{C}, 750^{\circ} \mathrm{C}$ and $850^{\circ} \mathrm{C}$, respectively. 
played the role of a copolymer or that the DMF solvents did not entirely volatilize (Figure 2a,b). The bands in the regions of 2934-2890, 1465-1445, 1385-1355, and 1270-1210 $\mathrm{cm}^{-1}$ were assigned to the aliphatic $\mathrm{CH}$ group vibrations of different modes in $\mathrm{CH}, \mathrm{CH}_{2}$ and $\mathrm{CH}_{3}$. After calcination from $550{ }^{\circ} \mathrm{C}$ to $850^{\circ} \mathrm{C}$, the absorption bands of PAN vanished due to decomposition and removal of the organic groups. The peak at $925 \mathrm{~cm}^{-1}$ was associated with $\mathrm{Mo}=\mathrm{O}$, while the prominent bands in the range of $500-850 \mathrm{~cm}^{-1}$ were attributed to Mo-O-Mo, indicating the occurrence of crystallization [28]. Both the Raman spectra and XRD results suggested that $\mathrm{MoO}_{2}-\mathrm{CNF}$ s were formed through a subsequent annealing process. The broad band at $3400 \mathrm{~cm}^{-1}$ was attributed to the $\mathrm{O}-\mathrm{H}$ stretching vibration due to absorbed $\mathrm{H}_{2} \mathrm{O}$ molecules on the nanofibers of $\mathrm{KBr}$.

A photo of the nonwoven PAN/PMA material is depicted in Figure 3a. The morphology of the as-prepared composite fibers and calcined fibers was further characterized by FE-SEM and TEM. The PAN/PMA composite fibers showed smooth surfaces due to their amorphous nature (Figure $3 \mathrm{~b}$ ). The average diameter of the as-prepared composite fibers was estimated to be $485 \mathrm{~nm}$. After calcination of the fibers at $550{ }^{\circ} \mathrm{C}$, the surface became rough and the average diameter decreased to $425 \mathrm{~nm}$.
The shrinkage and reduction in the fibers was caused by decomposition of PAN and subsequent crystallization. After calcination at $650{ }^{\circ} \mathrm{C}$ and $750{ }^{\circ} \mathrm{C}, \mathrm{MoO}_{2}-\mathrm{CNFs}$ showed discrete lengths with average diameters of $506 \mathrm{~nm}$ and $575 \mathrm{~nm}$, respectively. Also, the diameter of $\mathrm{MoO}_{2}-\mathrm{CNF}$ increased as the calcination temperature was increased, which can be explained by the gradual increase in grain size of $\mathrm{MoO}_{2}$ with sintering temperature. Interestingly, a change in fiber morphology was observed when the calcination temperature increased to $850{ }^{\circ} \mathrm{C}$. The nanofibers consisted of connected particles or crystallites, which is consistent with previous reports [29]. Further structural characterization of the as-prepared $\mathrm{MoO}_{2}-\mathrm{CNFs}$ was performed by TEM. Figure $3 \mathrm{~g}$ shows a typical TEM photograph of the nanostructures, displaying $\mathrm{MoO}_{2}$ nanoparticles decorated with carbon nanofibers. The elemental EDX of $\mathrm{MoO}_{2}-\mathrm{CNF}$ depicted in Figure $3 \mathrm{~h}$ indicates the presence of elemental Mo, $\mathrm{O}, \mathrm{C}$ and $\mathrm{Cu}$. The $\mathrm{Cu}$ signal comes from the $\mathrm{Cu}$ grid. The HRTEM image indicated that the grown structure was single crystalline with a lattice spacing of $0.344 \mathrm{~nm}$, corresponding to the [11] crystal plane of monoclinic $\mathrm{MoO}_{2}$ (Figure 3i).

SEM images of pure sulfur and $\mathrm{S} / \mathrm{MoO}_{2}-\mathrm{CNF}$ composites are displayed in Figure 4a,b, respectively. The sulfur morphology
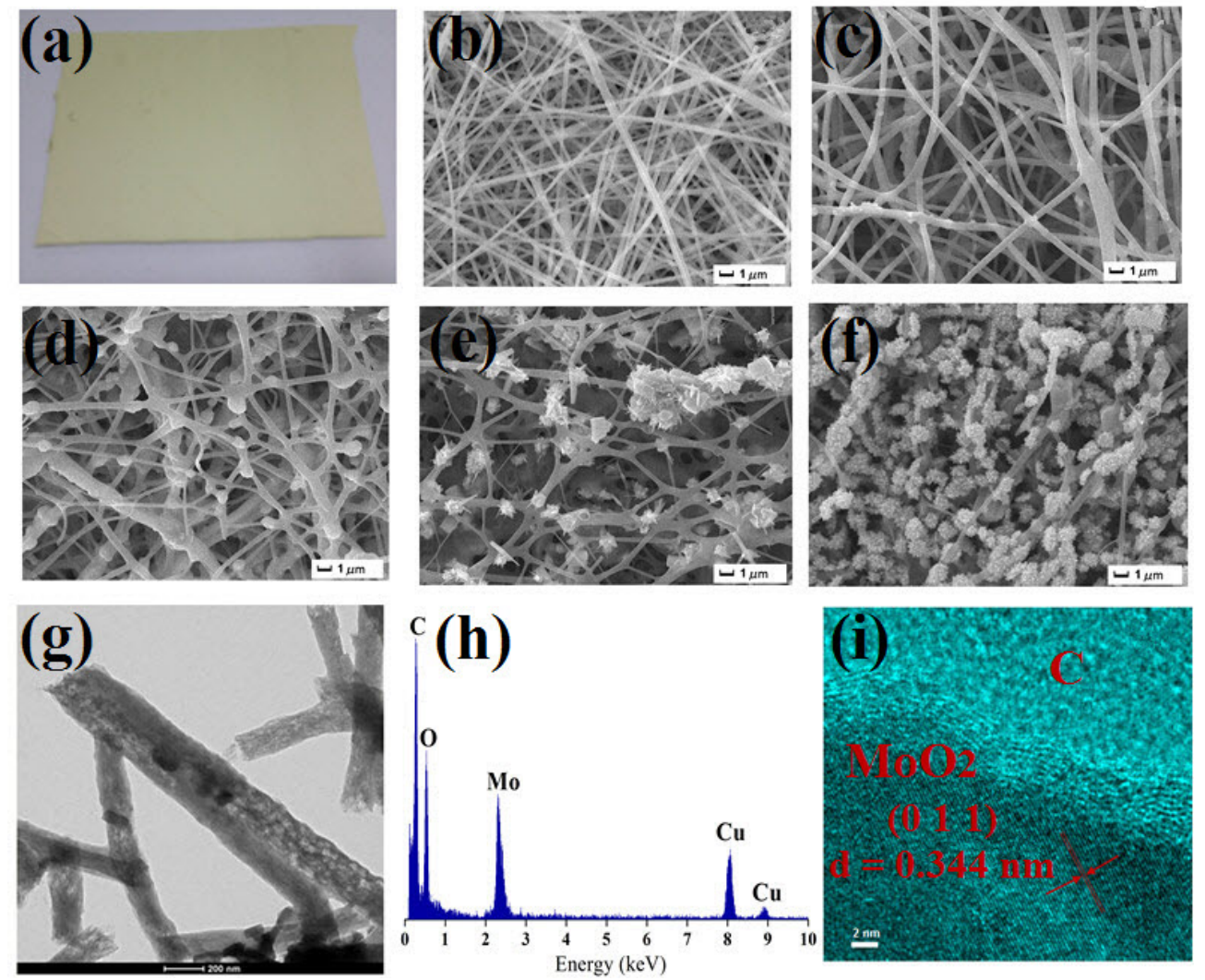

Figure 3: (a) A photo of nonwoven PAN/PMA fabric. SEM images of (b) as-prepared PAN/PMA composite fibers, (c--f) fibers calcined at $550{ }^{\circ} \mathrm{C}$, $650^{\circ} \mathrm{C}, 750^{\circ} \mathrm{C}$ and $850^{\circ} \mathrm{C}$. (g) TEM image of $\mathrm{MoO}_{2}-\mathrm{CNF}$ calcined at $850^{\circ} \mathrm{C}$. (h) EDX elemental line analysis and (i) HRTEM image of MoO $2-\mathrm{CNFs}$. 
(a)

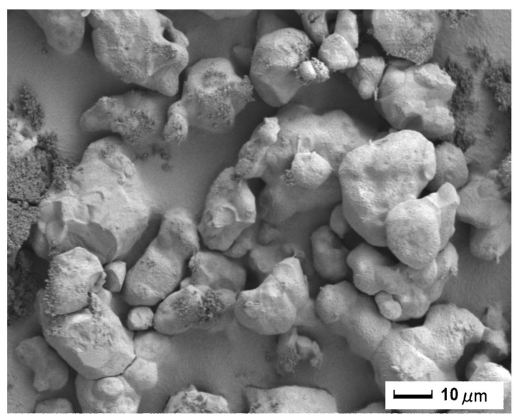

(c)

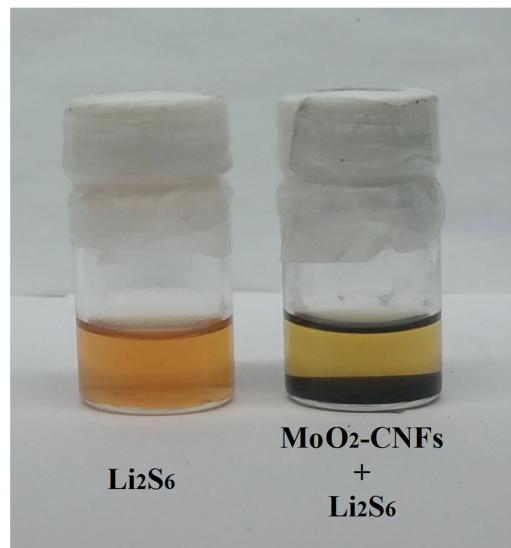

(b)

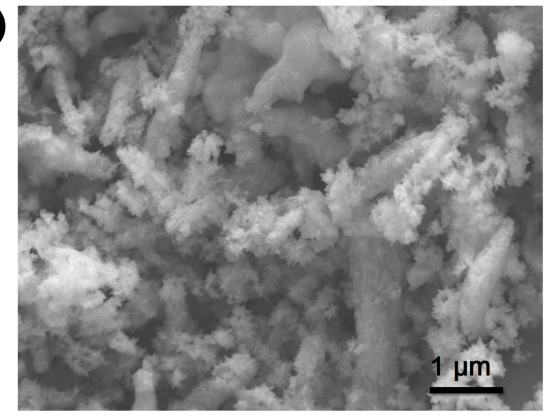

(d)

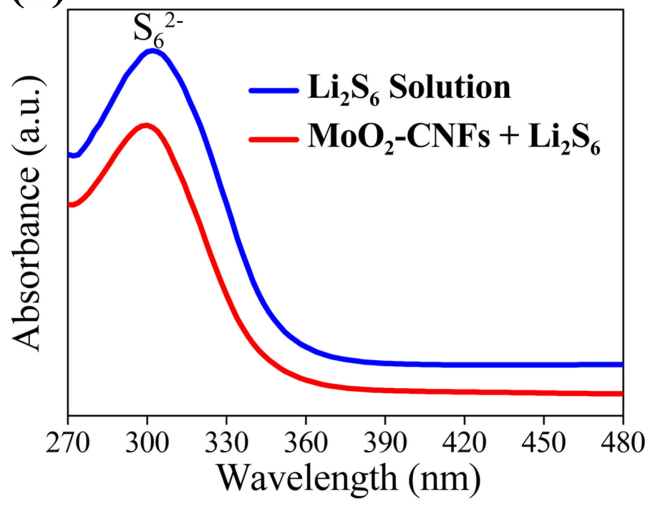

Figure 4: SEM image of (a) pure sulfur, (b) $\mathrm{MoO}_{2}-\mathrm{CNF}$ /sulfur composite. (c) Optical photo of $\mathrm{Li}_{2} \mathrm{~S}_{6}$ adsorption on $\mathrm{MoO}_{2}-\mathrm{CNFs}$ and (d) UV-vis absorption spectra of the $\mathrm{Li}_{2} \mathrm{~S}_{6}$ solution before and after the addition of $\mathrm{MoO}_{2}-\mathrm{CNFs}$.

was drastically changed from smooth to rough agglomerated particles upon the addition of $\mathrm{MoO}_{2}-\mathrm{CNF}$. The $\mathrm{MoO}_{2}-\mathrm{CNF}$ acted as a conductive matrix and facilitated the dispersion of sulfur with smaller particle size, which could favor ion diffusivity in the cathode due to the reduction in the Li-ion pathways. To further evaluate the interaction between $\mathrm{MoO}_{2}-\mathrm{CNFs}$ and polysulfides, the as-prepared $\mathrm{MoO}_{2}-\mathrm{CNFs}$ were added into $\mathrm{Li}_{2} \mathrm{~S}_{6}$ solution. In the optical photo of Figure $3 \mathrm{c}$, the original yellow-brown solution turned lighter, indicating a strong adsorption. Meanwhile, UV-visible absorption spectroscopy was used to analyze the change in concentration of $\mathrm{Li}_{2} \mathrm{~S}_{6}$ before and after the addition of $\mathrm{MoO}_{2}-\mathrm{CNF}$. The polysulfide solution showed a broad absorption region between 270 and $330 \mathrm{~nm}$, with characteristic peaks located at approximately $300 \mathrm{~nm}$, ascribed to $\mathrm{S}_{6}{ }^{2-}$ species [30]. After absorption for $0.5 \mathrm{~h}$, a large decrease in the absorption peak intensity of the solution with $\mathrm{MoO}_{2}-\mathrm{CNFs}$ at $300 \mathrm{~nm}$ was identified, which confirmed the improved absorption capability of the composite fibers for polysulfidies.

\section{Electrochemical performance of $\mathrm{S} / \mathrm{MoO}_{2}-\mathrm{CNF}$ electrodes}

The electrochemical performance of cells with $\mathrm{S} / \mathrm{MoO}_{2}-\mathrm{CNF}$ based electrodes were evaluated by cyclic voltammetry $(\mathrm{CV})$ galvanostatic charge-discharge and electrochemical impedance spectroscopy (EIS).

The electrochemical characteristics of the cells with $\mathrm{S} / \mathrm{MoO}_{2}-\mathrm{CNF}$ cathodes and pure sulfur cathodes were examined by $\mathrm{CV}$ in the voltage range of $1.7-3.0 \mathrm{~V}$ at the scanning rate of $0.1 \mathrm{mV} \mathrm{s}^{-1}$, as shown in Figure 5a. Among these samples, all the CV curves appeared in the range of 1.93-2.05 V, 2.15-2.28 $\mathrm{V}$ and $2.41-2.52 \mathrm{~V}$, which are typical redox reactions of $\mathrm{Li}-\mathrm{S}$ batteries [31,32]. Meanwhile, the $\mathrm{CV}$ data confirm that the $\mathrm{MoO}_{2}-\mathrm{CNF}$ additive is not electrochemically active in the selected voltage region. Additionally, when comparing the $\mathrm{CV}$ of the pure sulfur electrode, a distinguishable positive shift in the reduction-oxidation peaks of the sulfur $/ \mathrm{MoO}_{2}-\mathrm{CNF}$ composites can be observed, which confirms a relatively low potential polarization with $\mathrm{MoO}_{2}-\mathrm{CNF}$ additives. An interesting point to note is that the highest current density of the $\mathrm{S} / \mathrm{MoO}_{2}-\mathrm{CNF}$ cathodes with $\mathrm{MoO}_{2}-\mathrm{CNF}$ calcined at $850{ }^{\circ} \mathrm{C}$ indicates enhanced reaction kinetics in the charge-discharge process. Furthermore, from Supporting Information File 1, Figure $\mathrm{S} 1$, the coin cell of sulfur $/ \mathrm{MoO}_{2}-\mathrm{CNF}\left(850{ }^{\circ} \mathrm{C}\right)$ also showed the lowest voltage hysteresis $(\Delta V)$ among the cells, suggesting a highly facile electrochemical redox reaction and low resistance [33]. These findings demonstrated that 

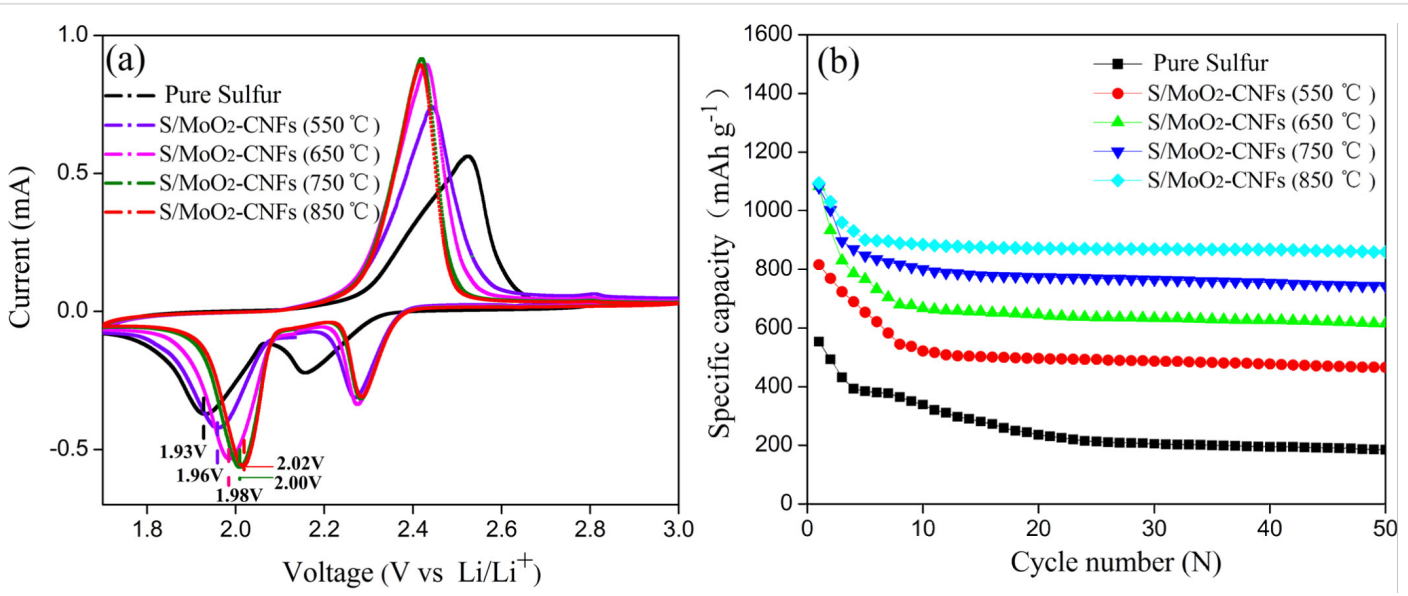

Figure 5: (a) The CV curves of cells assembled with $\mathrm{S} / \mathrm{MoO}_{2}-\mathrm{CNF}$ cathodes and pure sulfur cathodes. (b) Cycling performance of $\mathrm{MoO}_{2}-\mathrm{CNF}$ calcined at different temperatures with $\mathrm{S} /$ composite cathodes and pure sulfur cathode at $0.25 \mathrm{~mA} \mathrm{~cm}^{-2}$.

$\mathrm{MoO}_{2}-\mathrm{CNFs}$ improve the electrochemical reaction kinetics during the charge-discharge process.

Figure $5 \mathrm{~b}$ presents the cycling performance of the cells assembled from sulfur cathodes with and without $\mathrm{MoO}_{2}-\mathrm{CNF}$ calcined at different temperatures. The cell assembled with the pure sulfur electrode revealed lower initial discharge capacity. After a few cycles, the discharge capacity reduced from $554 \mathrm{mAh} \mathrm{g}^{-1}$ to $186 \mathrm{mAh} \mathrm{g}^{-1}$. Compared to the pure sulfur cathode, the cathode performance clearly improved when $\mathrm{MoO}_{2}-\mathrm{CNF}$ s were present in the sulfur matrix. The initial discharge capacity of the $\mathrm{S} / \mathrm{MoO}_{2}-\mathrm{CNF}$ cathodes with $\mathrm{MoO}_{2}-\mathrm{CNFs}$ calcined at $550,650,750$, and $850{ }^{\circ} \mathrm{C}$ were recorded as $816,1082,1079$, and $1095 \mathrm{mAh} \mathrm{g}^{-1}$, respectively. The improved performance with the addition of $\mathrm{MoO}_{2}-\mathrm{CNFs}$ could be attributed to the polysulfide adsorption and improved electrochemical reaction kinetics of $\mathrm{MoO}_{2}$, demonstrated by the initial specific capacity and $\mathrm{CV}$ curves. Meanwhile, the $\mathrm{S} / \mathrm{MoO}_{2}-\mathrm{CNFs}$ (calcined at $850{ }^{\circ} \mathrm{C}$ ) retained the highest capacity of $860 \mathrm{mAh} \mathrm{g}^{-1}$ after 50 cycles. The performance of the $\mathrm{MoO}_{2}-\mathrm{CNF}$ matrix for application in $\mathrm{Li}-\mathrm{S}$ batteries is also compared with several other carbon nanofibers and metal oxides fibers (Table 3), which further demonstrates the long-life behavior of the sulfur $/ \mathrm{MoO}_{2}-\mathrm{CNF}$ cathode.

The EIS technique was used to investigate the effect of the $\mathrm{MoO}_{2}-\mathrm{CNF}$ matrix material calcined at different temperatures on the electrochemical performance of the sulfur cathode. Compared to the $\mathrm{CV}$ technique, the diffusion coefficients under equilibrium conditions can be expressed by electrochemical impedance spectroscopy (EIS). Additionally, the chargetransfer reaction and lithium ion diffusion in the interface of solid electrodes can be derived [38,39]. Figure 6a displays the Nyquist plots of pure sulfur and $\mathrm{S} / \mathrm{MoO}_{2}-\mathrm{CNF}$ electrodes.
Table 3: Performance comparison of $\mathrm{MoO}_{2}-\mathrm{CNFs}$ with other matrices for application in Li-S batteries.

\begin{tabular}{lll} 
Matrix & Cycle performance & Ref. \\
\hline $\mathrm{MoO}_{2}-\mathrm{CNFs}$ & $\begin{array}{l}860 \mathrm{mAh} \mathrm{g}^{-1} 0.25 \mathrm{~mA} \mathrm{~cm}^{-2}(\approx 0.1 \mathrm{C}) \\
\text { per } 50 \mathrm{cycles}^{-1}\end{array}$ & $\begin{array}{l}\text { this } \\
\text { work }\end{array}$ \\
$\mathrm{CNFs}$ & $207 \mathrm{mAh} \mathrm{g}^{-1} 0.1 \mathrm{C}$ per 50 cycles & {$[34]$} \\
$\mathrm{CNFs}$ & $390 \mathrm{mAh} \mathrm{g}^{-1} 0.1 \mathrm{C}$ per 100 cycles & {$[35]$} \\
VGCFs & $335 \mathrm{mAh} \mathrm{g}^{-1} 0.1 \mathrm{C}$ per 40 cycles & {$[36]$} \\
$\mathrm{CNFs}$ & $560 \mathrm{mAh} \mathrm{g}^{-1} 0.1 \mathrm{C}$ per 50 cycles & {$[37]$} \\
$\mathrm{Mg}_{0.6} \mathrm{Ni}_{0.4} \mathrm{O}$ & $435 \mathrm{mAg} \mathrm{g}^{-1} 0.1 \mathrm{C}$ per 20 cycles & {$[12]$} \\
fibers &
\end{tabular}

Each Nyquist plot consists of a semicircle in the high to medium frequency region and a sloping line in the low frequency region. The equivalent circuits compatible with the Nyquist diagrams are represented in the inset of Figure 6a, which contain the solution resistance $\left(R_{\mathrm{S}}\right)$, the charge-transfer resistance of the electrode $\left(R_{\mathrm{ct}}\right)$ and a constant phase element corresponding to the double-layer capacitance (CPE). A steep sloping line in the low-frequency region, corresponding to the Warburg impedance, was represented by $W_{0}$. The fitting results are listed in Table 4. Obviously, the $\mathrm{S} / \mathrm{MoO}_{2}-\mathrm{CNF}$ cathodes possessed lower charge transfer resistance than pure sulfur cathodes, indicating better charge transfer between the sulfur and $\mathrm{MoO}_{2}-\mathrm{CNF}$ materials. This suggested sufficient contact among sulfur and $\mathrm{MoO}_{2}-\mathrm{CNFs}$, which lowered the resistance for the electron transfer across the interface between both. For further confirmation, the lithium ion diffusion coefficient was calculated using Equation 2 [40,41]:

$$
D_{\mathrm{Li}}=\frac{R^{2} T^{2}}{2 A^{2} n^{4} F^{4} C^{2} \sigma^{2}},
$$



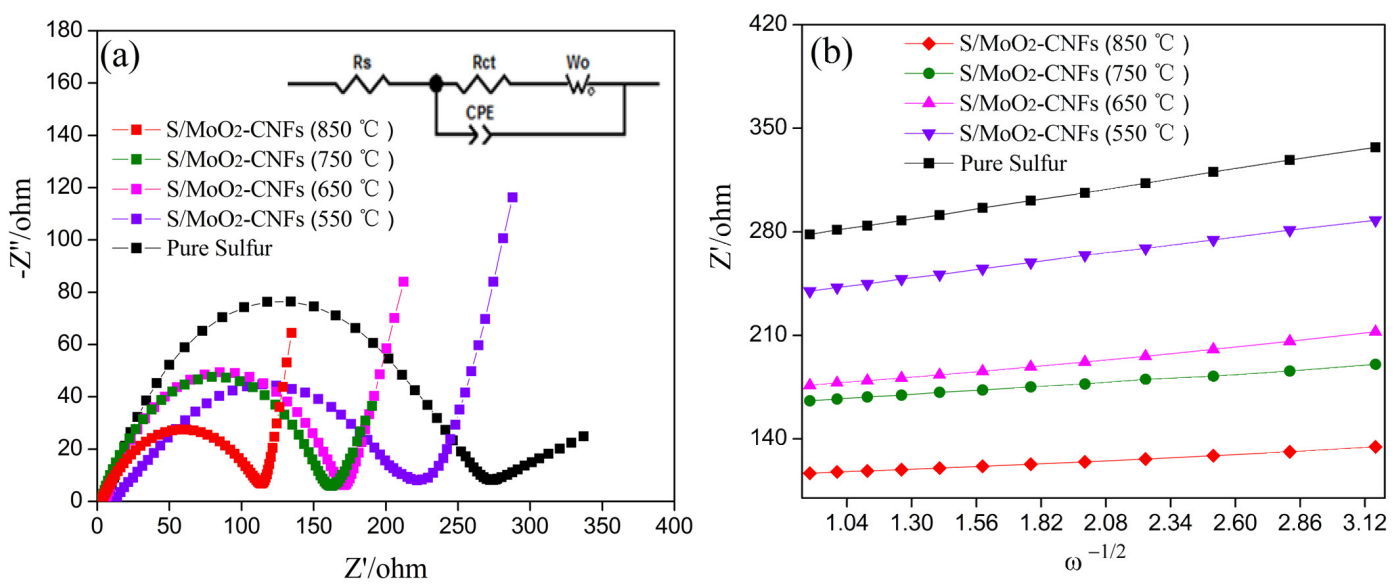

Figure 6: (a) Electrochemical impedance spectroscopy of $\mathrm{MoO}_{2}-\mathrm{CNFs}$ calcined at different temperatures with sulfur cathodes and a pure sulfur cathode. (b) The dependence of $Z^{\prime}\left(Z_{\text {re }}\right)$ on the reciprocal square root of the frequency $\omega^{-1 / 2}$ in the low-frequency region of five electrodes.

Table 4: Impedance parameters of the electrodes.

\begin{tabular}{|c|c|c|c|}
\hline Electrodes & $R_{\mathrm{S}}(\Omega)$ & $R_{\mathrm{ct}}(\Omega)$ & $D_{\mathrm{Li}}\left(\mathrm{cm}^{2} \mathrm{~s}^{-1}\right)$ \\
\hline sulfur/MoO ${ }_{2}-\mathrm{CNF}\left(850^{\circ} \mathrm{C}\right)$ & 1.387 & 113.92 & $8.42 \times 10^{-14}$ \\
\hline sulfur/MoO${ }_{2}-\mathrm{CNF}\left(750^{\circ} \mathrm{C}\right)$ & 1.584 & 161.15 & $4.38 \times 10^{-14}$ \\
\hline sulfur/MoO${ }_{2}-\mathrm{CNF}\left(650^{\circ} \mathrm{C}\right)$ & 2.614 & 169.53 & $2.05 \times 10^{-14}$ \\
\hline suflur/ $\mathrm{MoO}_{2}-\mathrm{CNF}\left(550^{\circ} \mathrm{C}\right)$ & 3.004 & 221.59 & $1.16 \times 10^{-14}$ \\
\hline pPure sulfur & 3.052 & 274.34 & $7.71 \times 10^{-15}$ \\
\hline
\end{tabular}

where $D_{\mathrm{Li}}$ represents the diffusion coefficient of the lithium ion, $R$ is the gas constant, $T$ is the absolute temperature, $A$ is the surface area of electrode, $n$ is the number of electrons per molecule during the reaction, $F$ is the Faraday constant, $C$ is the concentration of lithium ions, and $\sigma$ is the Warburg factor calculated through Equation 3 [40,41],

$$
Z_{\mathrm{re}}=R_{\mathrm{s}}+R_{\mathrm{ct}}+\varphi \omega^{-1 / 2}
$$

where $\varphi$ is the slope of the plots and $Z_{\mathrm{re}}$ is the reciprocal root square at the lower angular frequencies $\left(\omega^{-1 / 2}\right)$, presented in Figure $6 b$.

\section{Conclusion}

$\mathrm{MoO}_{2}-\mathrm{CNF}$ materials were prepared using the electrospinning process of PAN/PMA mixtures, followed by calcination treatments. XRD, FTIR and Raman results suggest that $\mathrm{MO}_{2}-\mathrm{CNFs}$ were obtained after being calcined at $550{ }^{\circ} \mathrm{C}$ and complete removal of the inorganic compound. The SEM images showed that the as-prepared $\mathrm{MO}_{2}-\mathrm{CNF}$ composite fibers had a smooth surface which turned to rough after calcination, revealing the increased crystallinity of $\mathrm{MoO}_{2}$ associated with the rise of the calcination temperature. The obtained $\mathrm{MoO}_{2}-\mathrm{CNF}$ s were applied to a sulfur matrix for $\mathrm{Li}-\mathrm{S}$ batteries and shown to exhibit high capacity when compared to electrodes with pure sulfur. The improved electrochemical performance could be attributed to the adsorption of polysulfide and acceleration of the electrochemical reaction kinetics during the charge-discharge process. The EIS results demonstrated that $\mathrm{S} / / \mathrm{MoO}_{2}-\mathrm{CNF}$ composites display a markedly higher lithium-ion diffusion coefficient, a low interfacial resistance and much better electrochemical performance than the pristine sulfur cathode. The proposed electrospinning technique might open new avenues for making promising nanofibers for practical applications.

\section{Experimental \\ Synthesis of $\mathrm{MoO}_{2}-\mathrm{CNFs}$}

Phosphomolybdic acid (PMA: $\mathrm{H}_{3} \mathrm{PO}_{4} \cdot 12 \mathrm{MoO}_{3}$ ), polyacrylonitrile (PAN, $\left.M_{\mathrm{W}}=150,000\right)$ and $N, N$-dimethylformamide (DMF) were purchased from Sinopharm Chemical Reagent Co., Ltd. All the reagents were used as-received without further purification.

In a typical procedure, a PAN solution (10 wt \%) was prepared by dissolving PAN powder in DMF and stirring for $12 \mathrm{~h}$. Next, PMA ( $3 \mathrm{~g}$ ) was added to the above solution and vigorously stirred for $24 \mathrm{~h}$ at room temperature to form a sol-gel solution for further electrospinning. The solution was then loaded into $10 \mathrm{~mL}$ plastic syringes equipped with a 9-gauge stainless steel needle. A high voltage power supply was used to provide a voltage of $15 \mathrm{kV}$ to the needle tips and the rotating drum collector covered by aluminum foil served as the counter electrode. The distance between the needle tips and drum collector was set to $18 \mathrm{~cm}$ and the flow rate of the solution to $0.5 \mathrm{~mL} \mathrm{~h}^{-1}$. The as-prepared electrospun nanofibers were preoxidized at $260{ }^{\circ} \mathrm{C}$ for $2 \mathrm{~h}$ in air and calcined at different temperatures for $4 \mathrm{~h}$ under argon atmosphere. Scheme S1 in Supporting 
Information File 1 illustrates the procedure used for preparing $\mathrm{MoO}_{2}-\mathrm{CNFs}$.

\section{Preparation of $\mathrm{S} / \mathrm{MoO}_{2}-\mathrm{CNF}$ electrodes}

Sulfur/ $\mathrm{MoO}_{2}-\mathrm{CNF}\left(\mathrm{S} / \mathrm{MoO}_{2}-\mathrm{CNF}\right)$ composites were prepared by mixing sulfur and $\mathrm{MoO}_{2}-\mathrm{CNF}$ in a mortar at the weight ratio of 1:1. The resulting $\mathrm{S} / \mathrm{MoO}_{2}-\mathrm{CNF}$ composites were gradually dried in air for $6 \mathrm{~h}$ then heated to $155^{\circ} \mathrm{C}$ for $6 \mathrm{~h}$ in a sealed $25 \mathrm{~mL}$ teflon-lined stainless-steel autoclave. After cooling down to room temperature, $\mathrm{S} / \mathrm{MoO}_{2}-\mathrm{CNF}$ composites were obtained. Next, the as-prepared $\mathrm{S} / \mathrm{MoO}_{2}-\mathrm{CNF}$ composites were mixed with acetylene black and polyvinylidene fluoride (PVDF) in $N$-methyl-2-pyrrolidone (NMP) at a weight ratio of 7:2:1. The slurry was spread onto aluminum foil (thickness: $20 \mu \mathrm{m}$ ) and dried in vacuum at $60^{\circ} \mathrm{C}$ for $12 \mathrm{~h}$. Electrodes were made from punching circular discs with a diameter of $12 \mathrm{~mm}$ and sulfur loadings of $1.5 \mathrm{mg} \mathrm{cm}^{-2}$ were applied. The thickness of the electrodes was $35 \mu \mathrm{m}$. For comparison, a pure sulfur cathode was prepared using the same procedure by mixing sulfur, acetylene black and PVDF at the weight ratio of 7:2:1. The $\mathrm{S} / \mathrm{MoO}_{2}-\mathrm{CNF}$ electrode is schematically displayed in Scheme S2 of Supporting Information File 1.

\section{Materials characterization}

The crystalline phases of the samples were determined by X-ray diffraction (XRD, Rigaku D/Mmax 2500PC) using $\mathrm{Cu} \mathrm{K} \alpha$ radiation $(\lambda=1.5406 \AA)$. The average grain size $(D)$ of the $\mathrm{MoO}_{2}$ nanoparticles was calculated using the Scherrer equation $(D=0.89 \lambda /(\beta \cos \theta))$, where $\lambda$ represents the wavelength of the $\mathrm{X}$-ray diffraction, $\beta$ is the full width at half maximum of the relevant diffraction peak, and $\theta$ is the diffraction angle. The Raman spectra were recorded on an American Themo-Fisher spectrometer using an $\mathrm{Ar}^{+}$laser at $532 \mathrm{~nm}$. The Brunauer-Emmett-Teller (BET) surface area was determined by nitrogen adsorption-desorption using a NOVA 2000e analyzer. The presence of functional groups was examined by Fourier transform infrared spectrometry (FTIR, Avatar-370 spectrometer) using the standard method of $\mathrm{KBr}$ in the scanning range of $400-4000 \mathrm{~cm}^{-1}$. The size and morphology of the fibers was determined by scanning electron microscopy (SEM, JSM-7001F). Details concerning the morphology and structure were examined by high-resolution transmission electron microscopy (HRTEM, Tecnai G2 F30), operated at an accelerating voltage of $200 \mathrm{kV}$. Selected specimens were examined with energy dispersive X-ray (EDX) spectroscopy and elemental mapping attached to the HRTEM operating at $200 \mathrm{kV}$.

The adsorption ability was determined by preparing a $\mathrm{Li}_{2} \mathrm{~S}_{6}$ solution through the addition of $\mathrm{Li}_{2} \mathrm{~S}$ to sulfur at the molar ratio of 1:5 in tetrahydrofuran (THF) under stirring. The obtained solution containing about $1.8 \mathrm{mg} \mathrm{mL}^{-1} \mathrm{Li}_{2} \mathrm{~S}_{6}$ was used for the sulfide adsorption test. $\mathrm{MoO}_{2}-\mathrm{CNFs}$ were added to $10.0 \mathrm{~mL}$ of $\mathrm{Li}_{2} \mathrm{~S}_{6} / \mathrm{TFH}$ solution and the mixture was adequately stirred for $0.5 \mathrm{~h}$. The ability of the $\mathrm{MoO}_{2}-\mathrm{CNF}$ composite to adsorb $\mathrm{Li}_{2} \mathrm{~S}_{6}$ was evaluated by UV-vis spectroscopy (UV-1800PC, Shanghai Mapada Instrument Co. Ltd).

\section{Electrochemical measurements}

The electrochemical performance of the samples was measured in CR 2032-type coin cells. The electrolyte contained $1 \mathrm{M}$ lithium bis(trifluoromethanesulfone)imide (LITFSI) and $0.1 \mathrm{M}$ $\mathrm{LiNO}_{3}$ dissolved in 1,3-dioxolane (DOL) and 1.2-dimethoxyethane (DME) at a volume ratio of 1:1. The electrolyte solution volume used in the cells was $75 \mu \mathrm{L}$. The coin cells were galvanostatically charged-discharged at $0.25 \mathrm{~mA} / \mathrm{cm}^{2}$ $\left(1 \mathrm{C}=1675 \mathrm{~mA} \mathrm{~g}^{-1}\right)$ and a voltage ranging from 1.7 and to $3.0 \mathrm{~V}\left(\mathrm{vs} \mathrm{Li} / \mathrm{Li}^{+}\right)$using a CT2001A cell test instrument (LAND model, Wuhan RAMBO testing equipment, Co. Ltd.). The CV and EIS measurements were conducted on a VMP2 electrochemical workstation (DHS Instruments Co. Ltd.). The CV curves were recorded at a scan rate of $0.1 \mathrm{mV} \mathrm{s}^{-1}$ in the voltage range of 1.7-3.0 V. The EIS spectra were measured in the frequency range of $0.1-100 \mathrm{kHz}$ with a disturbance amplitude of $10 \mathrm{mV}$.

\section{Supporting Information}

\section{Supporting Information File 1}

Additional experimental data and experimental schemes. [https://www.beilstein-journals.org/bjnano/content/ supplementary/2190-4286-9-28-S1.pdf]

\section{Acknowledgements}

This work was financially supported by the National Natural Science Foundation of China (Grant No. 51504101, 51474113), the Natural Science Foundation of Jiangsu Province (Grant No. BK20150514), the China Postdoctoral Science Foundation (Grant No. 2017M621640), the Natural Science Foundation of Jiangsu Provincial Higher Education of China (Grant No. 15KJB430006), the Start-up Foundation of Jiangsu University for Senior Talents (Grant No. 15JDG014).

\section{References}

1. Fotouhi, A.; Auger, D. J.; Propp, K.; Longo, S.; Wild, M. Renewable Sustainable Energy Rev. 2016, 56, 1008-1021. doi:10.1016/j.rser.2015.12.009

2. Hua, W.; Yang, Z.; Nie, H.; Li, Z.; Yang, J.; Guo, Z.; Ruan, C.; Chen, X.; Huang, S. ACS Nano 2017, 11, 2209-2218. doi:10.1021/acsnano.6b08627

3. Juhl, A. C.; Schneider, A.; Ufer, B.; Brezesinski, T.; Janek, J.; Fröba, M. Beilstein J. Nanotechnol. 2016, 7, 1229-1240. doi:10.3762/bjnano.7.114 
4. Wu, X.; Yao, S.; Hou, J.; Jing, M.; Qian, X.; Shen, X.; Xiang, J.; Xi, X. J. Nanosci. Nanotechnol. 2017, 17, 2482-2487. doi:10.1166/jnn.2017.13907

5. Zhong, J.; Wang, S.; Sha, Y.; Liu, M.; Cai, R.; Li, L.; Shao, Z. J. Mater. Chem. A 2016, 4, 9526-9535. doi:10.1039/C6TA03187K

6. Zhao, W.; Yu, Y.; Chen, H.; DiSalvo, F. J.; Abruña, H. D. J. Am. Chem. Soc. 2013, 135, 16736-16743. doi:10.1021/ja409508q

7. Evers, S.; Nazar, L. F. Acc. Chem. Res. 2013, 46, 1135-1143. doi:10.1021/ar3001348

8. Luan, K.; Yao, S.; Zhang, Y.; Zhuang, R.; Xiang, J.; Shen, X.; Li, T.; Xiao, K.; Qin, S. Electrochim. Acta 2017, 252, 461-469. doi:10.1016/j.electacta.2017.09.028

9. Xue, M.; Zhou, Y.; Geng, J.; Zeng, P.; Xu, Y.; Wang, Y.; Tang, W.; Wu, P.; Wei, S.; Zhou, Y. RSC Adv. 2016, 6, 91179-91184. doi:10.1039/C6RA19573C

10. Wei, S. Z.; Li, W.; Cha, J. J.; Zheng, G.; Yang, Y.; McDowell, M. T.; Hsu, P.-C.; Cui, Y. Nat. Commun. 2013, 4, 1331. doi:10.1038/ncomms2327

11. Li, Z.; Zhang, J.; Lou, X. W. Angew. Chem., Int. Ed. 2015, 54, 12886-12890. doi:10.1002/anie.201506972

12. Tang, H.; Yao, S.; Jing, M.; Wu, X.; Hou, J.; Qian, X.; Rao, D.; Shen, X.; Xi, X.; Xiao, K. J. Alloys Compd. 2015, 650, 351-356. doi:10.1016/j.jallcom.2015.07.264

13. Seh, Z. W.; Yu, J. H.; Li, W.; Hsu, P.-C.; Wang, H.; Sun, Y.; Yao, H.; Zhang, Q.; Cui, Y. Nat. Commun. 2014, 5, 5017. doi:10.1038/ncomms6017

14. Yuan, Z.; Peng, H.-J.; Hou, T.-Z.; Huang, J.-Q.; Cheng, C.-M.; Wang, D.-W.; Cheng, X.-B.; Wei, F.; Zhang, Q. Nano Lett. 2016, 16, 519-527. doi:10.1021/acs.nanolett.5b04166

15. Zhang, S. S.; Tran, D. T. J. Mater. Chem. A 2016, 4, 4371-4374. doi:10.1039/C6TA01214K

16. Yao, S.; Xue, S.; Zhang, Y.; Shen, X.; Qian, X.; Li, T.; Xiao, K.; Qin, S.; Xiang, J. J. Mater. Sci.: Mater. Electron. 2017, 28, 7264-7270. doi:10.1007/s10854-017-6410-z

17. Pang, Q.; Kundu, D.; Cuisinier, M.; Nazar, L. F. Nat. Commun. 2014, 5, 4759. doi:10.1038/ncomms5759

18. Pang, Q.; Kundu, D.; Nazar, L. F. Mater. Horiz. 2016, 3, 130-136. doi:10.1039/C5MH00246J

19. Hu, B.; Mai, L.; Chen, W.; Yang, F. ACS Nano 2009, 3, 478-482. doi:10.1021/nn800844h

20. Lu, Y.; Ang, H.; Yan, Q.; Fong, E. Chem. Mater. 2016, 28, 5743-5752. doi:10.1021/acs.chemmater.6b01966

21. Li, X.-y.; Xiao, Q.-g.; Gao, Y.-y.; Zhang, H.-I.; Xu, H.-b.; Zhang, Y. J. Alloys Compd. 2017, 723, 1113-1120. doi:10.1016/j.jallcom.2017.06.274

22. Yang, L. C.; Sun, W.; Zhong, Z. W.; Liu, J. W.; Gao, Q. S.; Hu, R. Z.; Zhu, M. J. Power Sources 2016, 306, 78-84. doi:10.1016/j.jpowsour.2015.11.073

23. Yang, L.; Li, X.; Quyang, Y.; Gao, Q.; Quyang, L.; Hu, R.; Liu, J.; Zhu, M. ACS Appl. Mater. Interfaces 2016, 8, 19987-19993. doi:10.1021/acsami.6b05049

24. Zhang, C.-L.; Yu, S.-H. Mater. Horiz. 2016, 3, 266-269. doi:10.1039/C6MH00045B

25. Liu, M.; Xie, W.; Gu, L.; Qin, T.; Hou, X.; He, D. Beilstein J. Nanotechnol. 2016, 7, 1289-1295. doi:10.3762/bjnano.7.120

26. Zhang, J.; Cai, Y.; Hou, X.; Song, X.; Lv, P.; Zhou, H.; Wei, Q. Beilstein J. Nanotechnol. 2017, 8, 1297-1306. doi:10.3762/bjnano.8.131
27. Li, H.; Hong, W.; Cui, Y.; Fan, S.; Zhu, L. J. Alloys Compd. 2013, 569, 45-51. doi:10.1016/j.jallcom.2013.03.165

28. Naouel, R.; Touati, F.; Gharbi, N. Solid State Sci. 2010, 12, 1098-1102. doi:10.1016/j.solidstatesciences.2010.04.015

29. Dharmaraj, N.; Park, H. C.; Lee, B. M.; Viswanathamurthi, P.; Kim, H. Y.; Lee, D. R. Inorg. Chem. Commun. 2004, 7, 431-433. doi:10.1016/j.inoche.2003.12.033

30. Han, K.; Shen, J.; Hao, S.; Ye, H.; Wolvertron, C.; Kung, M. C.; Kung, H. H. ChemSusChem 2014, 7, 2545-2553. doi:10.1002/cssc.201402329

31. Han, S.-C.; Song, M.-S.; Lee, H.; Kim, H.-S.; Ahn, H.-J.; Lee, J.-Y. J. Electrochem. Soc. 2003, 150, A889-A893. doi:10.1149/1.1576766

32. Babu, G.; Ababtain, K.; Simon, N. K. Y.; Arava, L. M. R. Sci. Rep. 2015, 5, 8763. doi:10.1038/srep08763

33. Cui, Z.; Zu, C.; Zhou, W.; Manthirma, A.; Goodenough, J. B. Adv. Mater. 2016, 28, 6926-6931. doi:10.1002/adma.201601382

34. Lu, S.; Cheng, Y.; Wu, X.; Liu, J. Nano Lett. 2013, 13, 2485-2489. doi:10.1021/nl400543y

35. Yang, X.; Zhu, W.; Cao, G.; Zhao, X. RSC Adv. 2016, 6, 7159-7171. doi:10.1039/C5RA24129D

36. Wu, Y.; Gao, M.; Li, X.; Liu, Y.; Pan, H. J. Alloys Compd. 2014, 608, 220-228. doi:10.1016/j.jallcom.2014.04.073

37. Rao, M. M.; Geng, X. Y.; Li, X. P.; Hu, S. J.; Li, W. S. J. Power Sources 2012, 212, 179-185. doi:10.1016/j.jpowsour.2012.03.111

38. Huang, X.; Li, X.; Wang, H.; Pan, Z.; Qu, M.; Yu, Z. Electrochim. Acta 2010, 55, 7362-7366. doi:10.1016/j.electacta.2010.07.036

39. Cañas, N. A.; Hirose, K.; Pascucci, B.; Wagner, N.; Friedrich, K. A.; Hiesgen, R. Electrochim. Acta 2013, 97, 42-51. doi:10.1016/j.electacta.2013.02.101

40. Shenouda, A. F.; Liu, H. K. J. Electrochem. Soc. 2010, 157, A1183-A1187. doi:10.1149/1.3479425

41. Bard, A. J.; Faulkner, L. R., Eds. Electrochemical Methods: Fundamentals and Applications, 2nd ed.; John Wiley \& Sons, Inc.: New York, NY, U.S.A., 2001.

42. Fan, C.-Y.; Xiao, P.; Li, H.-H.; Wang, H.-F.; Zhang, L.-L.; Sun, H.-Z.; Wu, X.-L.; Xie, H.-M.; Zhang, J.-P. ACS Appl. Mater. Interfaces 2015, 7, 27959-27967. doi:10.1021/acsami.5b10300

\section{License and Terms}

This is an Open Access article under the terms of the Creative Commons Attribution License (http://creativecommons.org/licenses/by/4.0), which permits unrestricted use, distribution, and reproduction in any medium, provided the original work is properly cited.

The license is subject to the Beilstein Journal of Nanotechnology terms and conditions: (https://www.beilstein-journals.org/bjnano)

The definitive version of this article is the electronic one which can be found at: doi: $10.3762 /$ bjnano. 9.28 